Helgoländer wiss. Meeresunters. 17, 455-461 (1968)

\title{
Introduction to the studies of pollution in the Oslofjord
}

\author{
JoHAN T. RUUD \\ Institute of Marine Biology, University of Oslo, Oslo, Norway
}

KURZFASSUNG: Einführung in die Untersuchungen über die Verunreinigung im Oslofjord. Der Oslofjord erstreckt sich etwa $100 \mathrm{~km}$ in nördlicher Richtung vom Skagerrak bis nach Oslo. Bei Drøbak, etwa auf dem zweiten Drittel des Weges nach Oslo, gibt es eine Reihe von Hindernissen, die einem ungehinderten Austausch der Wassermassen im Fjord entgegenstehen. Der wichtigste Durchlaß ist nur etwa $300 \mathrm{~m}$ breit und hat eine Wassertiefe über der Schwelle von $19 \mathrm{~m}$. Hinter Drøbak besteht der Fjord aus zwei Becken, dem Westfjord und dem Bunnefjord, die Tiefen von $164 \mathrm{~m}$ beziehungsweise von $160 \mathrm{~m}$ aufweisen. Der Fjord hinter Drøbak hat eine Fläche von $191 \mathrm{~km}^{2}$; die Wassermenge beträgt nach Berechnungen 9,4 Milliarden $\mathrm{m}^{3}$. Der jährliche Zufluß an Süßwasser, das durch Abwässer von ca. 700000 Menschen und einer bedeutenden Industrie verunreinigt wird, beträgt etwa 800 Millionen $\mathrm{m}^{3}$. Studien über die Fauna wurden im 18. Jahrhundert von O. F. MülLER und im 19. Jahrhundert von M. und G. O. SARS vorgenommen. Ausgedehntere Untersuchungen wurden um 1900 von J. HJORT und H. H. GRAN begonnen. Seit Anfang der dreißiger Jahre sind diese Untersuchungen von den biologischen Instituten der Universität Oslo weitergeführt worden. 1953 wurde die Situation hinsichtlich der Verunreinigung des Fjords alarmierend. Die Behörden der Stadt Oslo wurden davon unterrichtet, daß umfassendere Untersuchungen notwendig seien, um die Folgen, die dadurch entstehen, daß der Fjord als Auffangbecken für die Abwässer der Stadt dient, zu erforschen. Das norwegische Institut für Wasserforschung NIVA (Norsk institutt for vannforskning), wurde gebeten, diese Untersuchungen vorzubereiten und zu leiten. Im Juni 1967 konnte das Institut seinen allgemeinen Bericht sowie 20 Spezialberichte über dieses Forschungsprojekt, das in den Jahren 1962 bis 1965 bearbeitet worden war, vorlegen.

\section{THE TOPOGRAPHY OF THE OSLOFJORD}

The Oslofjord penetrates inland over a distance of about 60 nautical miles from the open Skager-Rak to the capital city of Norway, Oslo. The fjord consists of a number of deep basins, separated by shallow sills. Through the outer part, a channel 3 to 4 miles wide, and $300 \mathrm{~m}$ deep, we enter a wider and more shallow area, the Breiangen, 10 to 15 miles across, and, in its deeper parts, mostly 130 to $140 \mathrm{~m}$ deep. From this area the Dramsfjord branches off to the northwest, while the main fjord continues north through the narrow Drøbak Sound, about 1 mile wide, 6 miles long and with a maximum depth of $200 \mathrm{~m}$.

At the town of Drøbak we encounter a series of obstacles to the free water exchange between the outer and inner fjord. An island divides the sound in two branches. The western branch is almost completely blocked by an artificial subsurface jetty; the eastern branch is partly blocked by a shoal $5 \mathrm{~m}$ deep and nearly centrally located in 
the sound. The chief navigational passage is to the west of this, in a channel about $300 \mathrm{~m}$ wide and with a sill depth of only $19 \mathrm{~m}$.

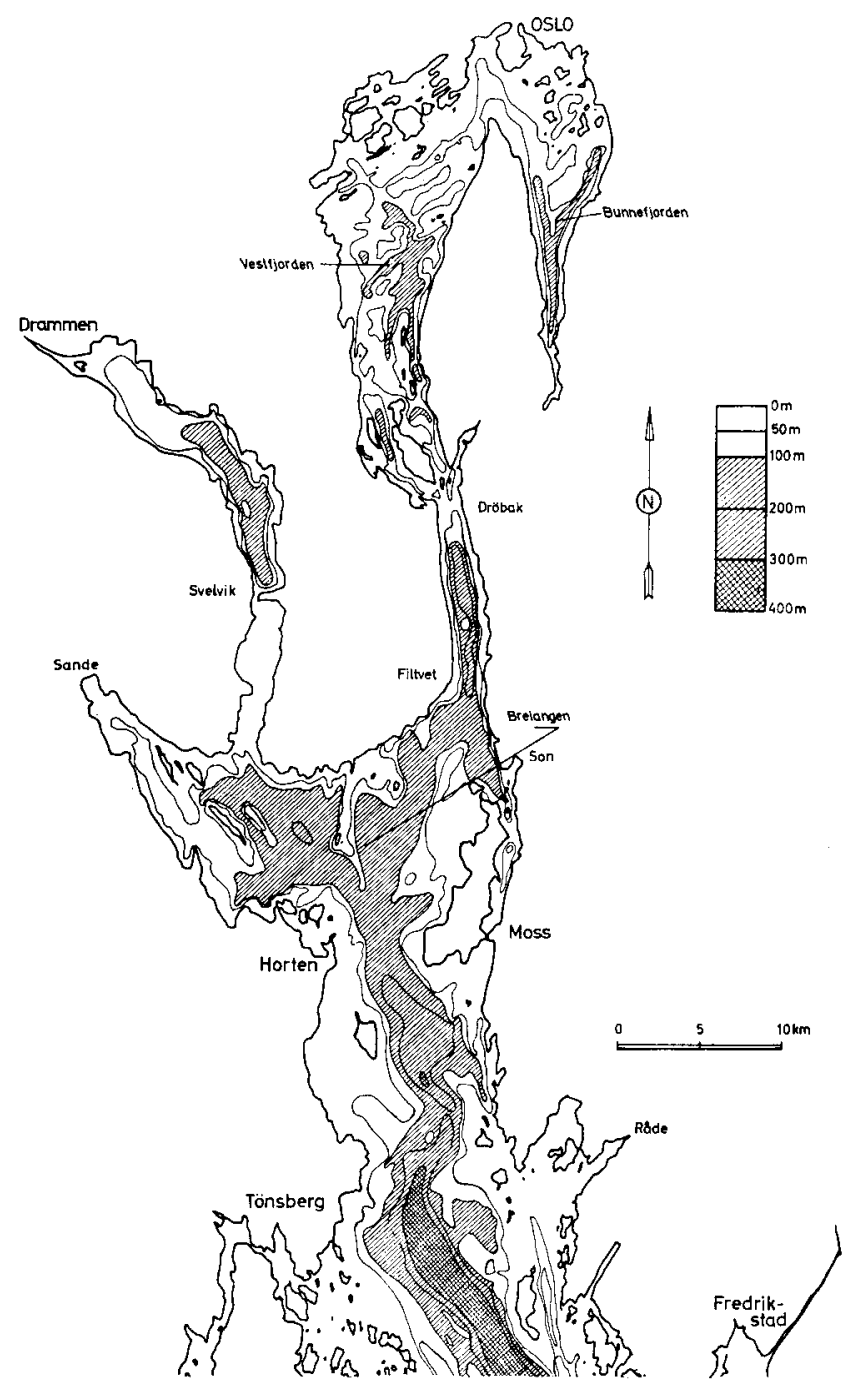

Fig. 1: Bathymetric chart of the Oslofjord

Inside the Drøbak sound, the fjord widens to about 4 miles in Vestfjorden, approximately 10 miles north of Drøbak. Passing northward, towards the harbour of Oslo, the fjord makes an eastward turn und pushes southward for about 9 miles. This part is called Bunnefjorden. 
The inner fjord, inside Drøbak, thus consists of two natural basins, which are separated by a sill about $50 \mathrm{~m}$ deep between the peninsulas Nesodden and Bygdøy.

The topography of the two basins corresponds well to the topography of the surrounding country; a series of rocky ridges separate deeper valleys, filled with clay and softer sediments. The deepest soundings in the two basins are 160 and $164 \mathrm{~m}$ respectively.

The surface area of the inner fjord is $191 \mathrm{~km}^{2}$, the mean depth is about $50 \mathrm{~m}$ and the total volume of water thus $9.4 \times 10^{9} \mathrm{~m}^{3}$. The mean freshwater discharge into the fjord is $26 \mathrm{~m}^{3} / \mathrm{sec}$; a good 800 million $\mathrm{m}^{3}$ per is year polluted by about 700 thousand people, by considerable industry and, to a lesser extent, by drainage from the surrounding fertilized farm land.

It is evident that the exchange of water through the Drøbak sound plays a decisive role for the conditions of the water masses in the inner fjord, especially since the difference between high and low water is only 20 to $30 \mathrm{~cm}$.

Along the Norwegian coast there is a considerable number of other deep fjords separated from the open sea by inlets blocked by shallow sills, where the saline water in the deeper layers is stagnant, completely void of oxygen, contains $\mathrm{H}_{2} \mathrm{~S}$ and thus is toxic to all aerobic life. The Dramsfjord is one of the typical cases where such conditions have prevailed for centuries. Others will report how parts of the inner Oslofjord, constantly or intermittently are exposed to similar conditions.

Thirty or forty years ago the inner Oslofjord was considered to be a fjord rich in edible fish. Professional fishermen landed annually, at the fish market in Oslo, 1500 to 2000 tons of fish caught inside Drøbak. Today the fishermen feel that their source of income is threatened by the increasing pollution of the fjord.

For the citizens of Oslo it is perhaps more important that the fjord is widely used as a resort for various sport, bathing, rowing, sailing and sport-fishing; they have in later years shown a growing concern about what is happening to their fjord. The citizens are now on the alert in regard to the danger threatening one of their favourite summer resorts, and discuss freely what ought to be done to arrest the development and to improve the situation.

\section{EARLIER STUDIES ON THE OSLOFJORD}

The first scientist studied the biology of the Oslofjord 200 years ago; it was O. F. Müller, a leading Danish zoologist. From the littoral zone at Drøbak he collected specimens which he described in "Zoologica Danica", published post mortem in four volumes between 1788 and 1806.

A hundred years later, M. SARs, professor of zoology at the University of Oslo, investigated the deeper waters, and in 1865 reported the finding of species in the deeper parts of the fjord which hitherto had only been recorded from arctic waters. Several publications by himself and his son G. O. SArs followed.

The zoological studies in the Oslofjord were continued by J. HJorT, when he was appointed director of the Biological Station at Drabak in 1897. In collaboration with H. H. Gran he also made the first hydrographical investigation of the fjord and 
GraN started his studies on phytoplankton. These investigations gave the first information on the hydrographical situation and emphasized the importance of wind transport of the surface layers from the outer to the inner part and vice versa.

Although no comprehensive investigation of the fjord was undertaken during the following 30 years, several studies of a more special nature were made. Among these may be mentioned the phytoplankton studies by GRAN and his collaborators, mainly in the Drøbak sound, and the investigations on the deep-sea prawn, Pandalus borealis, by HJORT \& RUUD, as well as the studies of the bottom fauna on the trawling grounds for prawns by BROCH. The results of the investigations during this period give a valuable point of reference from a time when the fjord was only slightly polluted.

As early as in 1917, GAARDER \& GRAN (1927) observed that phytoplankton populations in the area outside the Oslo harbour were especially large, and they suggested that it might be due to the discharge of sewage from the city. However, it was not until the early thirties, when an all-year hydrobiological survey was carried out by the Institute of Marine Biology at the University of Oslo, that it became evident that pollution had to be recognized as an important factor for the biology of the whole inner Oslofjord. On the basis of this survey, BraARud \& RuUd (1937) gave a comprehensive picture of the hydrography, with emphasis on the wind effect and the water exchange in the deep layers of the inner fjord. BRAARUd \& BURSA (1939) described a pronounced pollution effect upon the phytoplankton within the whole inner fjord, and WIBORG (1940) described the seasonal changes in composition and quantity of the zooplankton within the various parts of the fjord.

During the subsequent years, with an interruption during the war, a number of studies were carried out by the staff of the Institute of Marine Biology on the hydrography, chemistry, phytoplankton and zooplankton of the inner Oslofjord and, in most cases, the effect of pollution was a main issue. Among the more striking results may be mentioned the occurrence of critical situations in the deep waters of the Bunnefjord in 1950 to 1951, when these were found to be completely void of oxygen and contained $\mathrm{H}_{2} \mathrm{~S}$ from the bottom up to a depth of $75 \mathrm{~m}$ (BEYER \& FøYN 1951); in 1935 and 1937 the mass occurrence of the coccolithophorid Coccolitbus buxleyi with concentrations up to 35 millions per litre, caused an extremely low transparency and a pronounced discoloration of the fjord waters (BRAARUD 1945).

With the results of some 20 publications at hand, the situation became so alarming that in 1953 a memorandum was submitted to the authorities of the city of Oslo, in which the results available were summarized and their implications, as to the effect of the sewage discharge into the fjord, pointed out. It was stressed that more comprehensive, quantitative studies - especially of the water exchange between the outer and the inner fjord - were needed, and that the number of personnel and total expenses required would greatly exceed the capacity of the Institute of Marine Biology.

\section{THE OSLOFJORD PROJECT 1962 TO 1966}

The first reaction was not very positive; but when the Norwegian Institute for Water Research (NIVA) had been established in 1958, it was asked to present plans 
Table 1

List of reports of the Norwegian Institute for Water Research, Oslo, in the series The Oslofjord and its pollution problem: 1. The investigations 1962-1965. (All reports are written in Norwegian. Only report no. 19 and 20 have summaries in English)

\begin{tabular}{|c|c|c|c|}
\hline $\begin{array}{l}\text { Special } \\
\text { report } \\
\text { No. }\end{array}$ & Author & Original title & Translated title \\
\hline - & K. BAALSRUd & Samlerapport & General report \\
\hline 1 & H. Munthe-KaAs & $\begin{array}{l}\text { Overflatelagets } \\
\text { rekreasjonskvalitet }\end{array}$ & $\begin{array}{l}\text { Recreational quality of } \\
\text { the surface water }\end{array}$ \\
\hline 2 & H. G. GADE & Hydrografi & Hydrography \\
\hline 3 & J. T. RUUd \& J. VersviK & Fisket i Oslofjorden & Fisheries in the Oslofjord \\
\hline 4 & T. BraARUd \& I. NYgaARD & Fytoplankton & Phytoplankton \\
\hline 5 & $\begin{array}{l}\text { F. BEYER, Å. DYBWAD \& } \\
\text { ]. VERSVIK }\end{array}$ & Zooplankton & Zooplankton \\
\hline 6 & F. BEYER & $\begin{array}{l}\text { Bunnsedimenter og } \\
\text { bunnfauna i indre og } \\
\text { midtre Oslof jord i } 1938 \\
\text { og 1962-1966 }\end{array}$ & $\begin{array}{l}\text { Bottom sediments and } \\
\text { bottom fauna in the } \\
\text { inner and middle fjord } \\
\text { in } 1938 \text { and } 1962-1966\end{array}$ \\
\hline 7 & F. BEYER \& J. VersViK & $\begin{array}{l}\text { Undersøkelse av } \\
\text { virvelløse dyr langs med } \\
\text { bunnen av indre Oslo- } \\
\text { fjord i } 1962-1965\end{array}$ & $\begin{array}{l}\text { The invertebrates on and } \\
\text { near the bottom of the } \\
\text { inner Oslofjord in } \\
1962-1965\end{array}$ \\
\hline 8 & E. FOYN & $\begin{array}{l}\text { Vurdering av } \\
\text { næringssaltenes kjemi }\end{array}$ & $\begin{array}{l}\text { Chemistry of the } \\
\text { nutrients }\end{array}$ \\
\hline 9 & N. Klavestad & $\begin{array}{l}\text { Undersøkelse av } \\
\text { benthos-algevegeta- } \\
\text { sjonen i indre Oslo- } \\
\text { fjord i } 1962-1965\end{array}$ & $\begin{array}{l}\text { Growth of benthic algae } \\
\text { in the inner Oslofjord } \\
\text { in } 1962-1965\end{array}$ \\
\hline 10 & J. Kotai \& O. Skulberg & $\begin{array}{l}\text { En eksperimentell } \\
\text { undersøkelse av fjord- } \\
\text { vannets gjødslings- } \\
\text { påvirkning og den } \\
\text { resulterende algevekst }\end{array}$ & $\begin{array}{l}\text { An experimental } \\
\text { investigation of the } \\
\text { fertilization of the fjord } \\
\text { water and the resulting } \\
\text { growth of algae }\end{array}$ \\
\hline 11 & S.S. JOHANSEN & $\begin{array}{l}\text { Totaltilførsler av } \\
\text { forurensningskom- } \\
\text { ponenter via elver, } \\
\text { bekker og kloakk- } \\
\text { ledninger til indre } \\
\text { Oslof jord }\end{array}$ & $\begin{array}{l}\text { Pollutant substances } \\
\text { discharged to the fjord } \\
\text { through rivers, streams } \\
\text { and sewers }\end{array}$ \\
\hline 12 & E. FØYN & $\begin{array}{l}\text { Eldre kjemiske under- } \\
\text { søkelser }\end{array}$ & $\begin{array}{l}\text { Chemical investigations } \\
\text { prior to } 1962\end{array}$ \\
\hline 13 & T. Oftebro & $\begin{array}{l}\text { Paralyserende mus- } \\
\text { lingsgift i blåskjell } \\
\text { i Oslof jorden }\end{array}$ & $\begin{array}{l}\text { Paralytic shellfish poison } \\
\text { in mussels from the } \\
\text { Oslofjord }\end{array}$ \\
\hline 14 & H. Munthe-KaAs & Materialbalanse & Material budget \\
\hline 15 & H. Munthe-KaAS & Fjordens topografi & Topography of the fjord \\
\hline 16 & H. MunTHE-KaAS & $\begin{array}{l}\text { Felt-og } \\
\text { laboratorieundersøkelser }\end{array}$ & $\begin{array}{l}\text { Field and laboratory } \\
\text { work, Scope and } \\
\text { methods }\end{array}$ \\
\hline 17 & H. MUNTHE-KaAS & Data og databehandling & $\begin{array}{l}\text { The data and the data } \\
\text { treatment }\end{array}$ \\
\hline 18 & F. BEYER & $\begin{array}{l}\text { Representativiteten } \\
\text { av undersøkelses- } \\
\text { perioden 1962-1966 }\end{array}$ & $\begin{array}{l}\text { Discussion of the } \\
\text { representativity of the } \\
\text { investigation period } \\
1962-1966\end{array}$ \\
\hline 19 & O. M. JoHANNESSEN & $\begin{array}{l}\text { Strømundersøkelser } \\
\text { i Drøbaksundet, } \\
\text { Mai-Juni } 1963\end{array}$ & $\begin{array}{l}\text { Sea-current investi- } \\
\text { gations in the Drøbak } \\
\text { sound. May-June } 1963\end{array}$ \\
\hline 20 & O. M. JOHANNESSEN & $\begin{array}{l}\text { Strømkorsunder- } \\
\text { søkelser i Vestfjorden. } \\
\text { Juni } 1963\end{array}$ & $\begin{array}{l}\text { "Current-cross" } \\
\text { measurements in the } \\
\text { Westf jord. June } 1963\end{array}$ \\
\hline
\end{tabular}


for a research project on the effect of pollution upon the Oslofjord, with the ultimate target to propose technical solutions that would serve to arrest the detrimental development and to improve the conditions.

In 1961, NIVA submitted a plan for a 5-year project which involved the cooperation of the Institute of Marine Biology of the University of Oslo and the Geophysical Institute of the University of Bergen. The municipalities of Oslo and Bærum promised to pay the expenses, and later the 8 other municipalities bordering the inner Oslof jord joined, paying their shares of the total cost.

Mr. H. Munthe-KaAs was appointed project leader, and about 20 scientists and graduate students from the three institutions have taken part in field work and studies of material collected.

Two vessels have been engaged in more than 200 cruises; about 3000 stations were taken, about 1000 of them with samples for the study of some 15 parameters from all standard depths. This study is the most comprehensive one ever undertaken in a Norwegian fjord, and we expect that the results will be of value for similar studies to be conducted elsewhere.

The general report, edited by K. BAALSRUD, Director of NIVA, and 20 special reports edited by scientists participating in the project, were issued in June 1967. Appended is a list of the reports, all in Norwegian, with the titles translated into English. Most of them will later be published in English. The following articles by GADE, Munthe-KaAs, Føyn, Beyer and Ruud will give short summaries of results presented in special reports numbers, $1,2,3,5,6,7,8$ and 12 , respectively.

\section{SUMMARY}

1. The Oslofjord penetrates inland over a distance of about 60 nautical miles from the open Skager-Rak to the capital city of Norway. At the town of Drøbak, about $2 / 8$ up the fjord, there are a series of obstacles to a free exchange of water, the main passage being a channel about $300 \mathrm{~m}$ wide with a sill depth of $19 \mathrm{~m}$.

Inside Drøbak, the fjord consists of two wider basins, "Vestfjorden" and "Bunnefjorden" with depths down to 164 and $160 \mathrm{~m}$. The area of the inner fjord is $191 \mathrm{~km}^{2}$; it holds about $9.4 \times 10^{9} \mathrm{~m}^{3}$ of water. The discharge of freshwater is about $800 \mathrm{mil}-$ lion $\mathrm{m}^{3}$ per year, polluted by a population of 700 thousand and considerable industry,

2. Faunistic studies were made by O. F. Müller in the 18 th, M. and G. O Sars in the 19 th century, while more extensive hydrobiological studies were initiated by J. HJORT and H. H. GRAN about 1900 . They were subsequently extended through participation of the staffs of biological institutes of the University of Oslo, especially from the early thirties, when the importance of the pollution for the biology of the inner fjord had become well documented.

3. In 1953 the situation had become so alarming that the authorities of the city of Oslo were warned that the use of the fjord as recipient for the city sewage had detrimental effects which required their attention and that more comprehensive studies were needed. The Norwegian Institute of Water Research (NIVA) was 
asked to plan and direct the cooperative investigations which have been carried out in the years 1962 to 1965 . The Institute of Marine Biology of the University of Oslo and the Geophysical Institute of the University of Bergen participated in these studies.

4. This summer the results were reported to the supporting authorities in a general report, edited by K. BAalsRud, Director of NIVA, and in 20 special reports by participating scientists.

\section{LITERATURE CITED}

BEYer, F. \& Føyn, E., 1951. Surstoffmangel i Oslofjorden. Naturen 10, 289-306.

BRAarud, T., 1945. Forurensning og selvrensning av sjøvann. Undersøkelser $\mathrm{i}$ Oslofjorden. Naturen $\mathbf{7 / 8}, 212-235$.

- \& Bursa, A., 1939. The phytoplankton of the Oslofjord 1933-1934. Hvalraid. Skr. 19,1-63.

- \& Ruvd, J. T., 1937. The hydrographic conditions and aeration of the Oslo Fjord, 19331934. Hvalråd. Skr. 15, 1-56.

GAARDER, T. \& Gran, H. H., 1927. Investigations of the production of plankton in the Oslo Fjord. Rapp. P.-v. Réun. Cons. perm. int. Explor. Mer 42, 1-48.

WiBorG, K. F., 1940. The production of zooplankton in the Oslofjord 1933-1934. Hvalrad. $S k r .21,1-87$. 